\title{
'n Kennissosiologiese benadering tot die dag van die Here in 2 Petrus
}

\author{
Gert Malan \& Andries van Aarde \\ Departement Nurve-Testamentiese Wetensicap (APd A) \\ Universiteit van Pretoria
}

\begin{abstract}
The day of the Lord in 2 Peter from the perspective of the sociology of knowledge

The concept the day of the Lord in 2 Peter is, as a mythological expression, an example of analogical language. However, the meaning of this mytheme is not clear to modern people who do not share the mythological world-view of the author of 2 Peter. Although the historical roots of the day of the Lord has been thoroughly researched, the aspect of analogical language has not received much attention. The meaning of the day of the Lord needs to be axplored with the aid of a method which has the capacity to probe the meaning of analogical language. The sociology of knowledge offers such a method, especially with its potential to analyse symbolic universes. This article is an attempt at applying the sociology of knowledge to the day of the Lord in 2 Peter in order to render its meaning for modern readers.
\end{abstract}

Maar die hemel en die aarde van vandag is bestem en word bewaar vir die vuur, ook deur die woord van God, en word in stand gehou tot op die dag waarop die goddelose mense veroordeel en verdelg sal word (2 Pet 3:7).

Maar die dag van die Here sal so onverwags soos 'n dief kom. En op die dag sal die hemel met 'n groot gedruis verdwyn, die hemelliggame brand en tot niet gaan, en die aarde met alles wat daarup is, vergaan ( 2 Pet 3:10).

Leef in die verwagting dat die dag van God kom en beywer julle daarvoor, die dag waarop die hemel in vlamme sal vergaan en die hemelliggame sal brand en wegsmelt (2 Pet 3:12).

\footnotetext{
* Hiendie artikel is 'n verwerking van die resultate van 'n deel uit die DD-proefskrif, ingedien en annvar as deel vas die vereistes vir die DD-grand (1998), Departement Nuwe-Testamentiese Wetenskep, Falulteit Teologie (Afdeljing A), Universiteit van Pretoria, onder leiding van prof dr A G van Aarde.
} 


\section{INLEIDING}

Hoe moet die apokaliptiese beskrywing van die oordeelsdag as die dag van die Here verstaan word deur mense wat 'n moderne natuurwetenskaplike siening van die werklikheid huldig? Moet di verwagting van 'n letterlike vernietiging van die heelal deur vuur, met die gepaardgaande vergelding van die goddelose en vindisering van die getroue gelowiges, soos dit in 2 Petrus voorkom, presies net so aanvaar word, of behoort dit geag te word as mitologie wat geen betekenis meer het nie? Het die voormodeme oortuiging met betrekking tot die dag van die Here, soos uitgedruk in 2 Petrus, enigsins vir die twintigste-eeuse mens iets te sê, en indien wel, van watter belang sou hierdie uitdrukking vir die geloof en lewe wees?

Die blote aanvaarding en verstaan van 'n mitologiese en apokaliptiese uitdrukking soos die dag van die Here is geensins vir die moderne mens die vanselfsprekendheid wat dit vir die outeur van 2 Petrus was nie. Die rede daarvoor is die uiteenlopende sienings van die werklikheid wat gehuldig word deur beide die pole van outeur en moderne lesers. Die outeur van 2 Petrus het 'n tipies Nuwe-Testamentiese mitologiese, voorwetenskaplike siening van die werklikheid gehad, met ander woorde 'n wèreldbeeld wat oop is vir die ingrype deur God en God se engele, of die Satan en demone (vgl 2 Pet 2:4-11). Die wêreld is beskou as 'n drie-verdieping struktuur met die aarde tussen die hemel daarbo, en die hel daaronder, wat onderskeidelik dien as die woonpiekke van God en die engele, en die duiwel en die demone. Diegene wat getrou aan God bly, kan in die sekerheid leef dat die eindoordeel vir hulle heil sal inhou, terwyl die goddeloses en afvalliges die regverdige cordeel van God te wagte kan wees (vgl 2 Pet 3:3-15).

Vir die outeur van 2 Petrus is die eskatologie, en spesifiek die sekerheid oor die veroordeling van die goddeloses en die ewige heil van die getroue gelowiges, vir die ware geloof en die volhardende gehoorsaamheid aan God van die grootste belang (Lovestam 1984:287). Die doel van die brief is immers juis om te waarsku teen dwaalleraars wat die eindoordeel ontken (Seethaler 1985:69). Omdat die teologie van die brief as 't ware gebou word op die fondament van die eskatologie, is ons van mening dat daar met reg gepraat kan word van 'n besondere eskatologiese gerigtheid of perspektief (Neyrey 1977:10). In 2 Petrus word 'n unieke nuansering van die Nuwe-Testamentiese eskatologie aangetref. Die uniekheid lê aan die een kant daarin dat slegs hier in die Nuwe Testament daar sprake is van die vernietiging van die hemelliggame en die aarde deur vuur by die eindoordeel (Sidebottom 1967:95), en an die ander kant word slegs hier in die Nuwe Testament gebruik gemaak van Ps 90:4 om die uitbly van die eindoordeel te verklaar (Kelly 1969:362). Resente navorsers is dit eens dat die outeur se polemiek teen eskatologiese skeptisisme regdeur die brief aangetref word, en nie eers in die derde hoofstuk nie (Fomberg 1977:40, 47, 59, 78-93), wat daarop dui dat ons hier met die hoofmotief in die geskrif te make het. 
Die dag van die Here is een van die terme in 2 Petrus wat op die paroesie dui, en is 'n simboliese uitdrukking wat ontleen is aan die Ou Testament. Dit het nuwe betekenis gekry binne die eiesoortige eskatologiese gerigtheid van 2 Petrus. Hierdie term is 'n voorbeeld van wat bekend staan as analogiese taal of metaforiese taal. Analogiese taal word gebruik wanneer veronderstel word dat daar 'n ooreenkoms bestaan tussen twee objekte of sake. Oor die een saak waarvan ons minder weet, word daar gepoog om iets meer te sê, deur te praat oor dit waarvan ons meer weet (McFague 1983:15).

Die begrip analogiese taal het sedert die filosofie van Immanuel Kant vir die teologie van besondere betekenis geword en is juis die gevolg van die groeiende invloed van die natuurwetenskappe. Die opkoms van die natuurwetenskappe het 'n fenomenale uitwerking op die filosofiese kennisleer, die metafisika en uiteindelik ook die teologie gehad. Kant het met sy Kritik der reinen Vernunft die fundamentele punt van die destydse metafisika, naamlik dat die leer aangaande siel, wêreld en God wetenskaplik van aard is en as sulks kenbaar is, afgebreek deur die toepassing van 'n dialektiese kennisleer (Dreyer 1990:583-584). Kant (1984:180-191) verdeel in sy kennisleer alle objekte in wat hy noem phenomena (Duits: Erscheinung) en noumena (Duits: die Ding an sich). Dit wat deur die rede en die sintuie beleef en geken word, verlaat nooit die grense van moontlike ervaring nie, en het met die phenomenon/Erscheinung te make en nie met die noumenon/die Ding an sich nie. Kant kom tot die gevolgtrekking dat ons nie anders oor God kan praat as in analogiese terme nie (Allen 1985:217). Dit beteken dat God nie as blote phenomenon beskou kan word wat vir die rede en sintuie toeganklik is nie, maar juis funksioneer as potensiele noumenon waarvan die rede wel 'n bepaalde idee kan hê, maar wat nie deur die rede of die sintuie bevestig kan word nie. Hierdie uitspraak is vir die teologie van enorme belang, want dit bring aan die een kant die erkenning dat teologie nie kan bestaan sonder analogiese of metaforiese taal nie, omdat alles wat oor God bekend is, deur analogiese taal aan ons deur die Bybel oorgedra is (Van Aarde 1991:55). Aan die ander kant bring die benadering van die NuweTestamentiese tekste as analogiese taal die erkenning dat hierdie tekste tog eksistensieel singewend binne die moderne tyd uitgelê kan word, en open dit inderdaad 'n verskeidenheid van moontlikhede om dit te doen (Van Aarde 1991:55-56).

Met betrekking tot die studie van die dag van die Here in 2 Petrus bestaan daar 'n navorsingsleemte, spesifiek omdat daar nie genoegsaam aandag gegee is aan die feit dat ons in hierdie uitdrukking te make het met analogiese taal nie. 'n Byna terloopse opmerking van Bauckham (1990:89-91) in sy kommentaar is hier van belang, naamlik dat die dag van die Here nie letterlik verstaan moet word nie. Die uitdrukking word bepaal deur 'n voorwetenskaplike wêreldbeeld, en het ten doel om 'n prentjie te skets van die Goddelike oordeel eerder as om die fisiese gebeure presies te voorspel. Die verwysing in die teks na die vernietiging van die aarde en heelal deur vuur, moet volgens Bauckman ook nie letterlik verstaan word nie maar as beeldspraak. In hierdie 
opsig gaan Bauckham 'n belangrike tree verder as die gewoon histories-kritiese en literêre eksegese wat die eskatologiese beeldspraak oor die dag van die Here slegs beskryf teen die agtergrond van die apokaliptiese motiewe en Hellenisties-heidense eskatologiese idees. By verre die meeste uitleggers is voorstaanders van die histories-kritiese uitleg van die Nuwe-Testamentiese tekste. Dit bring mee dat daar cor die jare aandag gegee is aan terreine wat eie is aan hierdie benadering.

Bauckham se opmerking hierbo is egter niks anders nie as 'n poging om te vra na die betekenis van hierdie stukkie analogiese taal, die intensie van die uitdrukking, en die vraag dan te beantwoord as synde 'n poging om iets in beperkte mensetaal oor God te sê. So beskou, is sy opmerking in lyn met die Kantiaanse stelling dat die transendente werklikheid nie as sulks kenbaar en onderskeibaar is nie, maar slegs deur analogieë en simbole (Hopper 1987:54). Juis omdat iemand (die outeur van die brief) so min weet oor ' $n$ saak (in hierdie geval die eindoordeel), kan dit betekenisvol toegelig word in terme van iets anders waarvan ons 'n bietjie meer weet. Dit is juis hier waar die navorsing tot op hede nie genoegsaam aandag gegee het aan die interpretasie van die begrip as analogiese taal nie.

Die keuse om die kennissosiologiese benadering ook op die teks toe te pas, het spesifiek met bogenoemde doeistelling te doen, omdat die kennissosiologie 'n benadering is wat rekening hou met die analogiese aard van taal. Ons insiens is die spesifieke kennissosiologiese benadering waarvan Peter Berger 'n bekende eksponent is, ideaal vir hierdie tak. Dit kan as 'n filosofies-fenomenologiese hermeneutiese benadering beskryf word (Van Staden 1990:67). Alhoewel hy die begrip simboliese taal gebruik in plaas van analogiese taal, stem die twee begrippe met mekaar ooreen. Hieroor sê Berger: Any significative theme that spans spheres of reality may be defined as symbol, and the linguistic mode by which such transcendence is achieved may be called symbolic language (Berger \& Luckmann 1975:55). Dit beteken dat op die vlak van simboliek, taal die maksimum verwydering van die hier en nou van die alledaagse lewe bereik, en terreine betree wat nie vir die alledaagse belewenis toeganklik is nie. Sodoende skep taal reusagtige simboliese voorstellings wat oor die werklikheid van elke dag toring.

Hierdie voorstellings of konstruksies staan binne die kennissosiologie bekend as simboliese universums, en juis op hierdie terrein lewer die kennissosiologie wat die teologie betref, sekerlik 'n baie belangrike bydrae (Van Staden 1988:344). Oniosmaaklik verbonde aan die simboliese universum is die sosiale universum as die sfeer van die daaglikse ontmoetings van aangesig tot aangesig. Die simboliese universum ontspring enersyds vanuit die sosiale universum, en andersyds dien dit as die hoogste vlak van legitimering van daardie sosiale universum (Petersen 1985:27-29).

Dit is verder belangrik om in te sien dat die simboliese universum, uit die aard van die oorsprong daarvan in die sosiale universum, 'n menslike produk is en derhalwe 
heelwat oor die mens te kenne gee. "The origins of a symbolic universe have their roots in the constitution of man. As man externalizes himself, he constructs the world into which he externalizes himself. In the process of externalization, he projects his own meanings into reality' (Berger \& Luckmann 1975:121-122). Die spesifieke betekenis wat mense oor die werklikheid in hulle simboliese universum projekteer, is myns insiens tegelyk 'n aanduiding van mense se denke oor hulleself en dit wat vir hulle eksistensieel singewend is. Dit stem ooreen met wat Van Staden (1988:341) as die sentrale probleem van die kennissosiologie aandui, naamlik die probleem van die existential determination (Seinsgebundenheit) of thought as such.

\section{2. 'N KENNISSOSIOLOGIESE BENADERING}

\subsection{Inleiding}

Mense is voortdurend besig met pogings om orde in hulle leefwêreld te vind of daar te stel, met die gevolg dat hulle op 'n abstrakte vlak 'n simboliese siening het van hoe die kosmos daaruit behoort te sien. Hierdie persepsie is gewoonlik implisiet en as kind aangeleer deur die proses van sosialisering. Hierdie tendens om orde te probeer vind of te skep, is tegelyk 'n poging tot selfdefiniëring. Chaos, die totale afwesigheid van enige orde, is en was vir mense 'n vreesaanjaende idee, want dit impliseer die afwesigheid van enige patrone, identifikasies, reels of strukture in die universum. Gevolglik neig mense daarna om orde op hulle wêreld af te dwing om dit verstaanbaar te maak en hulleself daarbinne te definieer (Neyrey 1991:273).

Een van die primére funksies van 'n Nuwe-Testamentiese teks is om die sosiale identiteit te-versterk van die groep/gemeente vir wie dit bedoel was (Meeks 1972:70). Dit geld veral wanneer die groep geisoleerd gestaan het van die groter gemeenskap, soos in die geval van die gemeente aan wie 2 Petrus gerig was. So 'n dokument verskaf aan gelowiges 'n simboliese universum wat legitimering op godsdienstige vlak vir hulle isolasie bied. Indien daar tot hierdie simboliese universum deurgedring kan word, kan daar veel begryp word oor die selfverstaan van daardie betrokke gemeenskap (Best 1983:183; vgl ook Kee 1995:11).

Die oorspronklike lesers van 2 Petrus was tweede-eeuse Mediterreense mense in die Grieks-Hellenistiese wêreld wat 'n eiesoortige kosmos, of simboliese universum, veronderstel. Hiendie simboliese universum is egter total anders as wat modeme mense s' $n$ is. Ons leef in ' $n$ toenemende post-industriële gemeenskap; hulle in 'n meer primitiewe agrariese opset. Ons is Westers en individualisties georiēnteerd; hulle was Mediterreens en groepsgerigte mense. Daar bestaan dus 'n kloof tussen die oorspronklike lesers en vandag se lesers wat nie misgekyk behoort te word nie (Neyrey 1990:12). Indien dit tog sou gebeur dat hierdie kloof misken word, kom dit neer op 'n 
modernisering van die vroeë kerk ten koste van die ware beeld daarvan. Daar behoort daamee rekening gehou te word dat die tekste in 'n bepaalde lewensverhouding spreek, wat geensins vandag net so gereprodusseer kan word binne enige kerk in die Westerse kultuur nie. Wat nodig is, is 'n metode wat dieper delf as die tradisionele historieskritiese metode. Juis hier is die kennissosiologiese benadering van groot waarde om die vreemdsoortigheid van die vroeë kerk binne die oorspronklike konteks bloot te lê. Die kennissosiologiese benadering van Berger is ' $n$ algemeen aanvaarde benadering wanneer gepoog word om tekste te lees vanuit die sosiale konteks waarin hulle ontstaan het (Best 1983:183-184).

\subsection{Metode/model vir vasstelling van simboliese universum}

Soos ons reeds vroeer daarop gewys het, is die kennissosiologiese benadering op sigself nie ' $n$ model om tekste mee te lees nie. Saam met die kulturele antropologie en ander sosiaal-wetenskaplike studies bied dit die hasis vir die daarstelling van 'n model vir die soeke na die simboliese universum waarbinne 'n bepaalde teks ontstaan het. Van Staden (1988:337-353) het na aanleiding van die kennissosiologiese insigte van Petersen, Berger en Luckmann 'n metode daargestel met die oog op die sistematiese bestudering van rolle, die sosiale instellings waarna die rolle verwys en die sosiale verhoudings wat ter sprake is, met die oog op die versamel van inligting oor die betrokke simboliese universum.

Sodra sekere vorme van sosiale handelinge tipies word, verkry dit 'n objektiewe betekenis, wat ook op die linguistiese vlak geobjektiveer word. Die gevolg daarvan is dat die akteurs wat hierdie rolle vertolk ook geobjektiveer word. 'n Sekere handeling word deur 'n sekere tipe akteur vertolk. Die institusionele orde word op twee vlakke deur rolle verteenwoordig: die rol verteenwoordig sigself, sowel as 'n sosiale instelling. So verteenwoordig die rol van die predikant in verhouding tot die ander rolle in die kerk, hierdie godsdienstige instelling. Slegs deur die verteenwoordiging in die uitgespeelde rolle kan die instelling sigself manifesteer. Dit beteken dat rolle dit vir sosiale instellings moontlik maak om te bestaan as ' $n$ werklikheid binne die veld van menslike belewenis (Van Staden 1988:343).

Sosiale instellings is die gevolg van die geroetineerde aard van gemeenskappe en die feit dat menslike aktiwiteite geneig is om tot gewoontes te lei. Juis hierdie saak van gewoontevorming is die noodsaaklike voorwaarde vir die vorming van sosiale instellings. Enige wedersydse tipering van handelinge wat gewoontes geword het, is ' $n$ aanduiding van 'n sosiale instelling wat uiteindelik 'n objektiewe kwaliteit verkry. So 'n instelling word beleef as ' $n$ werklikheid wat indiwidue konfronteer as 'n eksterne en dwingende saak (Van Staden 1988:342-343). 
Die analise van die rolle wat die akteurs in die teks speel, is volgens Van Staden (1988:343-344) van besondere belang vir die verstaan van Nuwe-Testamentiese tekste, omdat daar sekere gevolgtrekkings gemaak kan word oor die boodskap van die outeur, via sy of haar idees oor rolle en verhouding daarvan tot die sosiale instellings wat verteenwoordig word.

Hierdie artikel poog om aandag te gee aan die verskillende fasette van die simboliese universum van 2 Petrus. Om 'n algemene simboliese universum vas te stel wat vir Jesus en die Nuwe-Testamentiese tyd gegeld het, is reeds gedoen (vgl Neyrey 1990: 16-17). Dit is egter belangrik om raak te sien dat alle outeurs binne hierdie bree koepel hulle eie nuanserings het wat hulle unieke simboliese universum daarstel. Hierdie te onderskeie nuanserings kan alleen bepaal word deur die bestudering van die ter sake tekste self.

\section{2:3 Vasstelling van die rolle in die perikoop 2 Petrus 3:1-18}

\begin{tabular}{|c|c|c|c|}
\hline ROMEE & VERSE & PERSQNE & 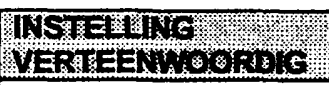 \\
\hline $\begin{array}{l}\text { Apostel/garant van die ware } \\
\text { egte tradisie/leraar van die } \\
\text { gemeente/bekendste } \\
\text { dissipel/rots waarop kerk } \\
\text { gebou is/een met sleutelmag }\end{array}$ & $3: 1$ & $\begin{array}{l}\text { Outeur, } \\
\text { Petrus }\end{array}$ & $\begin{array}{l}\text { Kerk/God se } \\
\text { orde/Koninkryk van } \\
\text { God }\end{array}$ \\
\hline Dwaalleraars/spotters & $3: 3-5$ & Onbekend & $\begin{array}{l}\text { Teenstanders van God } \\
\text { en God se orde }\end{array}$ \\
\hline Geliefdes & $\begin{array}{l}3: 1,8 \\
9,3: 10\end{array}$ & $\begin{array}{l}\text { Lesers, } \\
\text { onbekend }\end{array}$ & $\begin{array}{l}\text { Kerk/lidmate/ } \\
\text { bedreigdes }\end{array}$ \\
\hline Hemelse Regter & $\begin{array}{l}3: 7,9 \\
10\end{array}$ & God & $\begin{array}{l}\text { God se orde/God se } \\
\text { regspraak }\end{array}$ \\
\hline Dief & $3: 10$ & $\begin{array}{l}\text { d (se } \\
\text { g) }\end{array}$ & God se regspraak \\
\hline $\begin{array}{l}\text { Heerser (Woord van God } \\
\text { Heers) }\end{array}$ & $3: 13$ & God & Regering/regspraak \\
\hline Vlekkeloses/spotters & $3: 4$ & Ontroues & Regspraak (tipies) \\
\hline Ongeduldige & $3: 4$ & Ontroues & Tyd/kalenders (tipies) \\
\hline Geduldige & $3: 9,15$ & God & Tyd/kalenders (atipies) \\
\hline $\begin{array}{l}\text { Dié wat op verganklike dinge } \\
\text { vertrowaan begeerte toegee }\end{array}$ & $3: 3$ & Spotters & Ruimte/leefwereld \\
\hline $\begin{array}{l}\text { Vemietiger van wèreld en } \\
\text { heelal }\end{array}$ & $\begin{array}{l}3: 7,10 \\
12 \\
\end{array}$ & God & $\begin{array}{l}\text { Ruimte/leefwéreld/regs } \\
\text { praak }\end{array}$ \\
\hline $\begin{array}{l}\text { Skepper van ou en nuwe } \\
\text { wereld }\end{array}$ & $3: 5,13$ & God & $\begin{array}{l}\text { Ruimte/leefruimte/God } \\
\text { se orde }\end{array}$ \\
\hline
\end{tabular}




\subsubsection{Sosiale instellings waarna die rolle verwys}

Die oorheersende sosiale instelling is hier regspraak, verteenwoordig deur die rolle van regter, vromes/vlekkeloses/onberispelikes en spotters/valse leraars/goddeloses/sinlikes. Hierby skakel die rol van die dief in, hoewel dit meer die onaanvaarbare sosiale instelling van misdaad verteenwoordig. Deur die gebruik van pseudepigrafie word daar ook rolle geskep, naamlik die outeur as synde die apostel Petrus wat as garant van die ware leer optree en die rots is waarop die kerk gebou is en wat die sieutelmag ontvang het. Die gelowiges/getroues/vromes is hulle wat hierdie leer aanvaar, die kerk, wat op die rots bou. Die rolle wat hier ter sprake is, is dié van apostel/leraar wat met die lede/lidmate/geliefdes kommunikeer oor die belangrike saak van die uitbly van God se oordeel. Die kerk geld dus reeds as sosiale instelling wat via die rolle, geskep deur pseudepigrafie, op 'n spesifieke manier funksioneer. In die midde van die kerk, en tog ook teenoor die kerk se manier van funksionering via die rolle daarin en teenoor die apostèl/rots, staan die valse leraars en hulle volgelinge wat die kerk en die leer van binne bedreig.

\subsubsection{Interpretasie van die data}

\subsubsection{Uitspeel van die rolle}

a. Rolle gespeel deur die basiese akteurs:

\begin{tabular}{|l|l|}
\hline God se rolle: & Kerk se rolle: \\
\hline Regter/skepper/vernietiger/heerser/ & Apostel \\
Geduldige/dief & Petrus/rots/sleuteldraer/vromes/ \\
& geliefdes/gelowiges/spotters/ \\
& ongeduldiges/goddeloses/sinlikes \\
\hline
\end{tabular}




\section{b. Sosiale verhoudings}

Die sosiale verhoudings tussen die onderskeie rolle kan soos volg gekaart word:

\begin{tabular}{|c|c|c|}
\hline $\begin{array}{c}\text { Tipiese } \\
\text { Verhouding }\end{array}$ & verreulk & ing ingrmale \\
\hline REGTER & 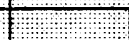 & ONTROUES \\
\hline Oordeel oor ontrou: vemietig ou hemel en aarde & $\longrightarrow$ & Vergeet dit \\
\hline Wag op bekering/geduldig met vemietigende oordeel & $\longrightarrow$ & Spot \\
\hline Sal vernietigend oordeel & $\longrightarrow$ & Ontken dit \\
\hline Oordeel kom soos 'n dief: onverwags & $\leftarrow$ & Nie gereed \\
\hline REEGER &  & IGEIROUES \\
\hline Oordeel regverdig: red hulle & $\leftarrow$ & Vlekkeloos, vroom \\
\hline Skep nuwe hemel en aarde & $\leftarrow$ & Verwag en glo dit \\
\hline Vermietigende oordeel & & $\begin{array}{l}\text { Glo en vrees dit, } \\
\text { leef vroom }\end{array}$ \\
\hline Oordeel kom soos 'n dief: onverwags & & Is gereed \\
\hline REGTER VYUYUY & & OUTEUR \\
\hline Oordeel regverdig & & $\begin{array}{l}\text { Glo dit; verkondig } \\
\text { dit }\end{array}$ \\
\hline Onverwagsheid van die oordeel & & $\begin{array}{l}\text { Glo dit; verkondig } \\
\text { dit }\end{array}$ \\
\hline Belofte van die oordeel & & $\begin{array}{l}\text { Glo dit; verkondig } \\
\text { dit }\end{array}$ \\
\hline OUTEUR & & KERK \\
\hline Gesagunlle verkondiger & & $\begin{array}{l}\text { Vromes aanvaar } \\
\text { en is getoorsaam }\end{array}$ \\
\hline Gesagvolle verkondiger & 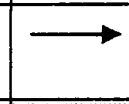 & $\begin{array}{l}\text { Spotters verwerp } \\
\text { dit en is } \\
\text { ongehoorsaam }\end{array}$ \\
\hline REGTER & & $\begin{array}{l}\text { WOREMOI: } \\
\text { LEERWLREIO }\end{array}$ \\
\hline Skep leefwêreld: ruimte en tyd & $\rightarrow$ & $\begin{array}{l}\text { Wêreldse mense } \\
\text { aanvaar dit } \\
\text { nie/vergeet dit }\end{array}$ \\
\hline Skep leefwêreld: ruimte en tyd & $\leftarrow$ & Vromes glo dit \\
\hline Vernietig wêreld van ruimte en tyd & $\pi$ & $\begin{array}{l}\text { Wêreldse mense } \\
\text { vernietig }\end{array}$ \\
\hline Vernietig wêreld van ruimte en tyd & & Vromes gered \\
\hline Skep nuwe leefruimte van geregtigheid & $\rightleftarrows$ & Geen vergelding \\
\hline KEERKR: & 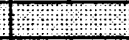 & WORELB: \\
\hline Spotters: begeerte oorheers/besmet/onreg & & Geen vergelding \\
\hline $\begin{array}{l}\text { Vromes: leef vlekkeloos/verwag nuwe } \\
\text { leefwéreld/regverdig }\end{array}$ & $\longrightarrow$ & $\begin{array}{l}\text { Geen vergelding } \\
\text { nou: verwag dit in } \\
\text { nuwe wereld, } \\
\text { ontvlug daarin } \\
\end{array}$ \\
\hline
\end{tabular}


Die regspraak van die Ou Testament kan waarskynlik veronderstel wees as die verwysings na die Ou Testament in 2 Petrus in gedagte gehou word, daarby dan spesifiek die Ou-Testamentiese motief van God se oordeel asook Nuwe-Testamentiese apokaliptiese motiewe (Elliott 1982:153; Vögtle 1994:230-239). Veral die gebruik van die

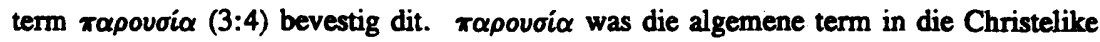
woordeskat vir die imminente koms van die verhoogde Heer, Jesus Christus in sy hemelse heerlikheid aan die einde van die geskiedenis (Elliott 1982:153).

Wat egter oor die algemeen nie in aanmerking geneem word nie, is dat die motiewe van die regspraak warskynlik ook bedoel was. om gelees te word teen die agtergrond van die Romeinse regsgebruike van die dag. Die term ro кpi $\mu \alpha$ (vonnis) in kombinasie met $\dot{\eta} \dot{\alpha} \pi \omega \lambda \boldsymbol{\lambda} \alpha \alpha$ (vernietiging) (2 Pet 2:3) is 'n bevestiging hiervan. Volgens Louw en Nida (1993a:364, 552-557; 1993b:147) kom die term ro xpi $\mu \alpha$ slegs in twee semantiese velde voor, naamlik corwegend in die veld van howe en regsprosedures, maar soms ook in die veld van denke, binne die subveld van onderskei, evalueer, beoordeel. In die konteks kan beide velde invloed op die betekenis van die term hê, en is die sosiologiese agtergrond van die regspraak myns insiens daarin veronderstel. $\dot{\eta}$ $\dot{\alpha} \pi \omega \lambda \varepsilon \alpha_{\alpha}$ val in die semantiese veld van geweld, benadeling, vernietiging en doodmaak, in die subveld vernietiging, asook in die veld waarde, in die subveld werd, waardeloos, met die konnotasie van waardeloosheid. Die betekenis binne konteks is dat iets as waardeloos verwerp of vernietig word (Louw \& Nida 1993a:232, 622; 1993b:32). Hierdie betekenis word ons insiens bepaal deur die regsterm to крí $\alpha$, sodat dit die konnotasie kry van die vel van die vonnis wat uitgespreek word.

Gesien vanuit die sosiale instelling van die regspraak, spesifiek die Romeinse reg van die cerste twee eeue, kry die hele saak van die dag van die Here besondere nuansering. Die heersers van die Romeinse Ryk het die wette uitgevaardig en soms het die betrokke wette saam met 'n heerser wat dit uitgevaardig het, gesterf. Stadhouers en landvoogde wat die regspraak hanteer het, was nie noodwendig mense met regskennis nie, en is derhalwe bygestaan deur juriste as adviseurs. Byna al die mag was in die hande van die keiser. Slegs die houer van die imperium kon die doodstraf ople. Hy kon ook 'n openbare bevel uitvaardig sonder inagneming van die bestaande wette (Van Aarde 1994:36). Die vertrekpunt vir die verstaan van 'n koning se heerskappy is die idee in die Hellenistiese wêreld dat die hele land die koning se persoonlike besitting was. Die konings het derhalwe oor die gebiede regeer soos wat gewone burgers oor hulle eie huishouding regeer het (Hengel 1974:19). Opmerklik is dat die term rapovoia (3:4) ook gebruik word vir die aankoms van 'n heerser (Elliott 1982:153), wat tegelyk ook regspraak moes behartig. Die idee dat selfs in hierdie wêreld die verkeerde nie ongestraf gelaat word nie, kan ter ondersteuning dien van die noodwendigheid van die goddelike cordeel. 
Net so is die benaming xúplos hier van belang. Hierdie benaming het moontlik nie net verwysing op die Ou-Testamentiese benaming יהוה of die Nuwe-Testannentiese xúpıs as benaming vir Christus nie, maar het moontlik ook verwysing na die sosiale konteks van die dag, en in besonder na hulle wat mag oor ander gehad het, here, meesters en heersers (Liddell \& Scott 1976:400). Om die rol te verstaan wat hier deur God as kúpwos vervul word, behoort hierdie aspek saam met die Ou- en Nuwe-Testamentiese motiewe ondersoek word. Die metaforiese aanwending van so 'n titel kan daarop dui dat God as die opperheerser, soos in die sosiale konteks, die regspraak hanteer, terwyl God tegelyk oor die heersersmag beskik. Die algemene verwagting van hierdie rolle was dat regverdig gehandel sal word en dat onreg nie geduld sal word nie.

Binne die Hellenistiese sosiale konteks was die debat oor die regverdige oordeel van die gode of die afwesigheid daarvan ook lewend (vgl die Epikureërs se verwerping daarvan). Volgens Neyrey (1980:261-302; 1993:239) kon juis hierdie saak die moont-


(3:4) kon ook gebruik word om die verskyning (epifanie) van 'n godheid aan te dui (Elliott 1982:153), terwyl die benaming kúplos ook vir gode gebruik is. In God se orde, dus ook in die kerk, is daar ' $\mathrm{n}$ atipiese benadering tot sekere sosiale rolle: Hy is regter en daar is vergelding soos wat daar van 'n regter in die sosiale orde verwag word. Wat egter nie tipies van 'n regter is nie, is om geen vergelding te bied nie. Wanneer daar geen reg is nie, gedy die onreg, soos met die spotters. God is tipiese regter omdat God sal vergeld, atipies omdat God die vergelding uitstel en die uitsonderiike mag het om die vergelding $\mathrm{cp}$ kosmiese vlak af te handel. Atipies is ook God se geduld met die oog op mense se bekering.

In God se orde word daar anders met tyd omgegaan as in die wêreld. Die wêreld reken met die gewone tydsindeling van dae en maande en jare, God nie, en laat hulle bestaan daardeur bepaal. Daar word ook in God se orde anders omgegaan met ruimte: die vromes/kerk as deel van God se orde vertrou nie op en leef nie vir hierdie verganklike wêreld nie. God sal uiteindelik hierdie wêreld vernietig en 'n nuwe wêreld van geregtigheid daarstel. Die sosiale instellings/grense waarbinne mense leef, naamlik ruimte en tyd, word dus deur God se orde omgekeer want God self stel die grense en invloed daarvan en oorskrei dit omdat God nie daaraan gebonde is nie. Hoewel die vromes/kerk steeds in die leefwêreld van tyd en ruimte leef, word die sinvolheid van hulle bestaan nie daardeur bepaal nie, maar deur God wat nie aan ruimte en tyd gebonde is nie maar daaroor heers. Wie an God (= aan God se werklikheid deel het/deelgekry het aan die goddelike natuur; vgl 1:4) behoort, laat hulle lewens bepaal deur God se hantering van tyd en me deur die mense s'n nie, en God se vernietiging/oordeel van die wêreld (ruimte/leefwêreld). 
Op tipiese wyse verteenwoordig God die regspraak, maar atipies vanweë die uitsonderlike mag waaroor God beskik. God speel die rol van regverdige regter, en voltrek ook self die vonnis, naamlik vernietig of red. Atipies tree God op soos 'n dief in die sin van die onverwagsheid van God se koms (steeds 'n beeld uit die regspraak, maar nie die verwagte een nie: die regter is tegelyk dief?). Dit is 'n bekende eskatologiese beeld in die Nuwe Testament (vgl Matt 24:43; Luk 12:39; 1 Tess 5:2). 'n Dief verteenwoordig die afwykende sosiale instelling van misdaad waarvan inbraak die tipiese optrede is, maar tegelyk sosiaal onaanvaarbaar is. Die fokus is op die onverwagsheid van hierdie sosiaal onaanvaarbare optrede. Die gevolgtrekking is dat die koms van die Regter vergelyk word met 'n dief, beide in die onverwagsheid as in die negatiewe konnotasie wat dit vir baie mense het (Van Staden 1988:347). In hierdie orde/kerk het die outeur 'n gesagvolle posisie: hy is die rots waarop hierdie orde gebou is. Sy uitspraak oor sake is gesagvol. Die outeur se leer oor die vergelding van die Goddelike regter legitimeer die orde in die kerk en dien as beskermende sambreel daarvoor. Aan die ander kant dien die gelowige en die gehoorsame aanvaarding van hierdie leer as sambreel teen die oordeel van die Goddelike regter.

Dit lyk asof juis die atipiese funksionering van rolle in God se orde vir die spotters moeilik was om te aanvaar. Die spotters keer daarom die orde in die kerk om deur nie die leer oor die vergelding te erken nie, maar tegelyk is daar dan geen beskerming vir hulle teen die kosmiese vergelding op die dag van die Here nie. Hier word duidelik twee verskillende simboliese universums aangetref wat elkeen 'n ander sosiale universum legitimeer. Die volgende struktuur kom uit die gedeelte na vore: Daar is 'n positiewe en negatiewe versterking vir volharding in vroomheid. Die nuwe hemel en aarde dien as redding en vindisering van die vromes, terwyl die kosmiese vernietigende oordeel van die leefwêreld op die spotters en ontroues wag.

So is daar ook positiewe en negatiewe versterking vir die oproep tot bekering: Die uitstel van die cordeel van God is slegs maar vanweë God se geduld met die oog op bekering van hulle wat ontrou geraak het. Negatief geld die onverwagsheid van die oordeel soos 'n dief se onverwagse inbraak. 


\subsubsection{Instellings en maniere van verwysing deur die rolle}

Die rolle binne die sosiale instelling van regspraak word gebruik om metafories iets oor die kerk te sê. Die verwysings kan soos volg gekaart word:

\begin{tabular}{|c|c|c|}
\hline WEREMD (LETIERIIKE VERWYSING) & & KERK \\
\hline Regter & $\longrightarrow$ & God \\
\hline Skuldiges & $\longrightarrow$ & Spotters \\
\hline Onskuldiges & $\longrightarrow$ & Vromes \\
\hline Dief & $\longrightarrow$ & God \\
\hline Mense wat gereed is & $\longrightarrow$ & Vromes \\
\hline Mense wat nie gereed is nie & $\longrightarrow$ & Spotters \\
\hline Gesagvolle boodskapper & $\longrightarrow$ & Outeur/geliefde \\
\hline Ontvangers wat boodskap ernstig neem & $\longrightarrow$ & $\begin{array}{l}\text { Vromes/bekeer } \\
\text {-linge/geliefdes }\end{array}$ \\
\hline Ontvangers wat boodskap verwerp & $\longrightarrow$ & Spotters \\
\hline Sender van boodskap & $\longrightarrow$ & $\begin{array}{l}\text { Jesus } \\
\text { Christus/God }\end{array}$ \\
\hline Verdraaiers van die boodskap & $\longrightarrow$ & Spotters \\
\hline
\end{tabular}

\section{Gevolgtrekking}

Die kennissosiologiese benadering tot die analogiese taal van die teks belig die simboliese universum van die outeur teenoor die bedreigende alternatiewe simboliese universum van die spotters. Die simboliese universum van die outeur is een waarin die regverdigheid van God 'n sleutelposisie beklee, terwyl die spotters juis hierdie saak ontken. Alhoewel die twee simboliese universums grotendeels met mekaar ooreenstem, word daar op hierdie punt radikaal verskil, met die gevolg dat daar in die sosiale universums wat onderskeidelik daardeur oorspan word, uiteenlopende idees is oor watter optrede eties aanvaarbaar sou wees.

Binne die sosiale veld van die kerk is die verhouding van die vromes tot God soortgelyk aan dié van onskuldiges voor 'n regter. Hulle leef in die verwagting van die regter se gunstige uitspraak, van die redding, en van die nuwe hemel en aarde. Soos in die sosiale orde, moet die vromes egter altyd baie versigtig wees om nie so op te tree dat hulle skuldig blyk te wees nie. Hulle word aan die verskrikking van die vernietigende kosmiese oordeel van God herinner, en ook dat dit totaal onverwags sal wees. Aan die ander kant staan die spotters/ontroues in die kerk in 'n verhouding met God 
wat soortgelyk is aan skuldiges voor 'n regter, maar dan een met 'n ontsagwekkende krag om te oordeel juis oor hulle wat sy oordeel betwyfel en afvallig raak. Daar kan maar een uitspraak en een vonnis wees, en tog is daar geleentheid vir terugkeer. Hierdie geleentheid word meegedeel saam met die boodskap van vergelding deur 'n gesagvolle boodskapper van die Regter, wat weer 'n geliefde/vriend van die vromes is.

Alhoewel moderne lesers nie dieselfde apokalipties-gekleurde simboliese universum as die outeur het nie, bied die kennissosiologiese benadering tot die analogiese taal van die teks die potensiaal dat die regverdigheid van God so duidelik belig word, dat moderne lesers hierdie aspek sinvol binne hulle simboliese en sosiale universums kan aanwend.

\section{Literatuurverwysings}

Allen, D 1985. Philosophy for understanding theology. Atlanta: John Knox.

Bauckham, R J 1990. Jude, 2 Peter. Dallas: Word. (Word Biblical Themes.)

Berger, P L \& Luckmann, T 1975. The social construction of reality: A treatise in the sociology of knowledge. Harmondsworth: Penguin.

Dreyer, P S 1990. Die filosofie van Immanuel Kant en die Protestants-teologiese denkstrukture. HTS 46, 582-595.

Elliott J H 1982. James, 1-2 Peter, Jude. Minneapolis: Augsburg. (Augsburg Commentary on the New Testament.)

Formberg, T 1977. An early church in a pluralistic society: A study of 2 Peter. Lund: C B Boktryckeri. (Coniectanea Biblica, New Testament Series 9.)

Hengel, M 1974. Judaism and Hellenism: Studies in their encounter in Palestine during the early Hellenistic period, Vol 1. London: SCM.

Hopper, J 1987. Modern Theology, 1: Cultural revolutions and new worlds. Philadelphia: Fortress.

Kant, I 1984. Critique of pure reason. London: Dent.

Kee, H C 1989. Knowing the truth: A sociological approach to the New Testament interpretation. Minneapolis: Fortress.

Kelly, J N D 1969. The epistles of Peter and of Jude. London: A \& C Black.

Liddell \& Scott's Greek-English Lexicon. 1976. Oxford: Clarendon.

Louw, J P \& Nida, E A 1993a. Greek-English lexicon of the New Testament based on semantic domains, Vol 1: Domains. Cape Town: United Bible Society.

1993b. Greek-English lexicon of the New Testament based on semantic domains, Vol 2: Indices. Cape Town: United Bible Society.

Lovestamm, E 1984. Eschatologie und Tradition im 2. Petrusbrief, in Weinrich, W (ed), The New Testament Age, Vol 2, 287-300. 
McFague, S 1983. Metaphorical theology: models of God in religious language. London: SCM.

Meeks, W 1972. The man from heaven in Johannine sectarianism. JBL 91, 44-72.

Neyrey, J H 1977. The form and background of the polemic in 2 Peter. Ann Arbor: UMI Dissertation Services:.

1980. The form and background of the polemic in 2 Peter. JBL 99/3, 407431.

1990. Paul in other words: A cultural reading of his letters. Louisville: Westminster/John Knox.

1991. The symbolic universe of Luke acts: 'They tum the world upside down', in Neyrey, J H (ed), The social world of Luke-Acts: Models for interpretation, 271-304. Peabody, MA: Hendrickson.

Petersen, N R 1985. Rediscovering Paul: Philemon and the sociology of Paul's narrative world. Philadelphia: Fortess.

Seethaler, P-A 1985. 1. und 2. Petrusbrief/Judasbrief. Stuttgart: Verlag Katholisches Bibelwerk. (Stuttgarter Kleiner Kommentar, Neues Testament 16.)

Sidebottom, E M 1982. James, Jude, 2 Peter. Grand Rapids: Eerdmans. (The New Century Bible Commentary.)

Van Aarde, A G 1991. 'The most high God does not live in houses built by men ...': The relativity of the metaphor 'Temple' in Luke-Acts. Neotestamentica 25/1, 5164.

1994. Kultuurhistoriese agtergrond van die Nuwe Testament. Pretoria: Kital.

Van Staden, P 1988. A sociological reading of Luke 12:35-48. Neotestamentica 22, 337-353.

1990. Compassion - the essence of life: A social-scientific study of the religious symbolic universe reflected in the ideology/theology of Luke. Pretona: University of Pretoria. (HTS Suppl 3.)

Vögtle, A 1994. Der Judasbrief/Der zweite Petrusbrief. Düsseldorf: Benziger Verlag. (Evangelisch Katholischer Kommentar zum Neuen Testament XXII.) 